\title{
The role of lipopolysaccharide in the exposure of protective antigenic sites on the major outer membrane protein of Chlamydia trachomatis
}

\author{
Evangelia Vretou,* Evgenia Psarrou and Dimitra Spiliopoulou \\ Department of Biotechnology, Institut Pasteur Hellenique, 127 Avenue Vassilissis Sofias, Athens 11521, Greece
}

(Received 11 September 1991; revised 12 February 1992; accepted 28 February 1992)

\begin{abstract}
A species-specific monoclonal IgM antibody (mAb) 9BF8 directed against the major outer membrane protein (MOMP) of Chlamydia trachomatis neutralized several chlamydial serovars in a complement-independent manner. The presence of $\mathrm{Mg}^{2+}$ ions negated the neutralization in serovars $\mathrm{F}, \mathrm{L1}$ and $\mathrm{L2}$, but not in serovars A, B, E, D and K. The ability of monovalent Fab-fragments of this mAb to neutralize chlamydial infectivity in a Mgindependent manner suggested that conformational alterations on the chlamydial surface induced by the cation hindered the IgM but allowed the smaller Fab fragment access to its epitope. In order to determine the chlamydial component that binds $\mathrm{Mg}$, elementary bodies (EB) of serovars E and L1 were treated with EDTA at pHs 8 and 9. The infectivity of the treated EB and the amount of released LPS were determined. Only after EDTA treatment at pH 9, as the LPS release increased, did the binding of the mAb on the chlamydial surface become $\mathrm{Mg}$-independent. The infectivity of the EB was almost completely lost after such a treatment. These results suggest that the chlamydial LPS has the potential to modulate the exposure of antigenic sites on the MOMP, when it is crosslinked by $\mathrm{Mg}^{2+}$. They further imply that serovars protected by $\mathrm{Mg}$ and those that are not differ in the surface topology of one particular MOMP epitope, but are antigenically very similar. This difference might be of considerable importance in vivo.
\end{abstract}

\section{Introduction}

Chlamydia trachomatis is an obligately parasitic bacterium causing a variety of human diseases. Many of the pathogenic properties of this micro-organism appear to be related to its surface. Ligands for cell attachment and entry, as well as targets for immune attack, and antigens for potential vaccination must reside on the outer cell wall. The major outer membrane protein (MOMP) and the LPS are among the major constituents of the outer membrane. These major antigens have been shown to be in very close contact (Birkelund et al., 1988), but little is known about their spatial arrangement on the chlamydial cell surface and their possible interactions. Both antigens have been considered relevant for vaccine production. Immunization with recombinant LPS in animal models was not protective (Taylor \& Prendergast, 1987). Antibodies against the MOMP have been shown to protect in vitro and in vivo (Caldwell \& Perry, 1984; Peeling et al., 1984; Zhang et al., 1987). One of these studies emphasized that the protective capability of the antibodies depended upon the immunoaccessibility of

\footnotetext{
* Author for correspondence. Tel. 3016431 303; fax 3016423498 .
}

the target MOMP epitopes on the surface of chlamydiae (Zhang et al., 1987). In this paper, we report on the complement-independent neutralizing activity of a monoclonal antibody (mAb) directed against the MOMP, and on the potential of $\mathrm{Mg}^{2+}$ ions to induce conformational changes on the surface of the elementary bodies (EB) interfering with the protective action of the antibody. We further show that the $\mathrm{Mg}$-independent action of the antibody correlates with maximal release of LPS from the chlamydial outer membrane. Part of the data reported here were first presented by Vretou et al. (1991).

\section{Methods}

Growth and purification of chlamydial strains. The $C$. trachomatis strains used in this study were A (G-17), B (TW-5), C (TW-3), D (UW3), E (UW-5), F (UW-6), I (UW-12), K (UW-31), L1 (440), L2 (434), and L3 (404) and the $C$. psittaci meningopneumonitis strain (Mn). They were provided by the American Type Culture Collection (Rockville, MD) and the Centers for Disease Control (Atlanta, GA). Chlamydiae were grown in monolayers of cycloheximide-treated McCoy cells as described before (Vretou et al., 1989) and EBs were purified by centrifugation twice through $30 \%(w / v)$ sucrose. The final pellet was resuspended in either HSC buffer (HEPES/sucrose/cation; 
Vretou et al., 1989) or in PBS (0.14 M- NaCl, $0.026 \mathrm{M}-\mathrm{KCl}, 1 \cdot 4 \mathrm{mM}-$ $\mathrm{KH}_{2} \mathrm{PO}_{4}, 8 \mathrm{mM}-\mathrm{Na}_{2} \mathrm{HPO}_{4}$ ) containing $0.2 \mathrm{M}$-sucrose (S-PBS). It contained 3-5 $\mathrm{mg}$ protein $\mathrm{ml}^{-1}$ determined with the BioRad assay kit using Standard I.

Monoclonal antibodies. The production and characterization of mAbs against $C$. trachomatis has been described elsewhere (Vretou et al., 1992). mAb 9BF8, an IgM, has been determined to be a speciesspecific antibody by immunofluorescence, immunodot and immunoblotting techniques. mAbs OPG10 and $1 \mathrm{BC} 6$, both IG3, are genusspecific anti-LPS antibodies. mAbs 171 and 169, both IgGl, are directed against the $57 \mathrm{kDa}$ chlamydial heat shock protein (Morrison $e t$ $a l ., 1989)$ and the $60 \mathrm{kDa}$ OMP 2 protein, respectively (E. Vretou, in preparation). The antibodies were grown in ascites in pristane-primed Balb/c mice and purified according to Pouletty et al. (1988). The purity of the preparation was judged by SDS-PAGE in $12.5 \%(\mathrm{w} / \mathrm{v})$ polyacrylamide gels. SDS-PAGE and Western blots were done as described by Goswami et al. (1990). Fab fragments were obtained by trypsinization of the IgM mAb under reducing conditions (Bidlack \& Mabie, 1986). After reduction with cysteine, the IgM was digested with trypsin in the ratio $1: 50$ (trypsin:IgM) at $37^{\circ} \mathrm{C}$ for $4 \mathrm{~h}$. The reaction was stopped with trypsin inhibitor followed by alkylation with iodoacetamide. The reaction mixture was separated on a Superose FPLC column (Pharmacia). Fractions containing the Fab fragments were pooled and checked for purity on SDS-PAGE under reducing and non-reducing conditions (Bidlack \& Mabie, 1986).

In vitro neutralization assay. The assays were performed in 96-well plates (Costar). Chlamydial suspensions were adjusted with S-PBS to give 50-100 inclusions per field $(160 \times)$. They were incubated with continuous shaking with 1 vol. purified $\mathrm{mAb} 9 \mathrm{BF} 8$, an unrelated $\mathrm{mAb}$, or purified Fab fragments at $37^{\circ} \mathrm{C}$ for $45 \mathrm{~min}$. $\mathrm{Ca}^{2+}, \mathrm{Mg}^{2+}$ and HEPES were sometimes included, depending upon the experiment. A $100 \mu \mathrm{l}$ sample of the mixtures was used to infect triplicate $24 \mathrm{~h}$ McCoy cell monolayers $\left(5 \times 10^{4}\right.$ cells per well). After $60 \mathrm{~min}$ at $37^{\circ} \mathrm{C}$, the inoculum was removed, the cells washed once with PBS and $200 \mu$ of cycloheximide-containing medium was added. The plates were incubated at $37^{\circ} \mathrm{C}$ for $48 \mathrm{~h}$. After fixation with methanol, inclusioncontaining cells were visualized with $\mathrm{mAb}$ OPG 10 (ascites fluid diluted 1:1000 in PBS, $37^{\circ} \mathrm{C}, 30 \mathrm{~min}$ ) and an FITC-conjugated anti-mouse rabbit serum ( $1: 20$ dilution in PBS, $37^{\circ} \mathrm{C}, 15 \mathrm{~min}$, Dakopatts). The microtitre plates were inverted and viewed with a Zeiss-Axiophot equipped with epifluorescence. Five fields in each well were read in the test and controls, and an average was taken from the 15 fields. The results are expressed as a percentage of the inclusion-forming units (IFU) relative to control wells [(IFU control-IFU test/IFU control) $\times 100]$.

Antibody absorption/recovery assay. Samples $(100 \mu \mathrm{l})$ of mAb 9BF8 [0.160 $\mu \mathrm{g} \mathrm{mAb} 9 \mathrm{BF} 8 \mathrm{ml}^{-1}$ in PBS, $1 \%(\mathrm{w} / \mathrm{v})$ BSA, $0.1 \%(\mathrm{w} / \mathrm{v})$ Tween 20 (PBS/BSA/T)] were incubated with increasing amounts of purified EB from serovar $\mathrm{E}, \mathrm{Ll}$ and the $C$. psittaci meningopneumonitis strain $\mathrm{Mn}$ as control for $30 \mathrm{~min}$ at $37^{\circ} \mathrm{C}$ in the presence or absence of $1 \mathrm{mM}$ $\mathrm{MgCl}_{2}$. After centrifugation at $25000 \mathrm{~g}$ for $10 \mathrm{~min}$ the amount of $\mathrm{mAb}$ recovered in the supernatant was titrated in a capture-ELISA assay with rabbit serum against mouse immunoglobulins (Dakopatts) as the immobilized antibody (Nunc plates, $10 \mu \mathrm{g} \mathrm{ml}^{-1}$ in $0.05 \mathrm{M}$-carbonate/bicarbonate buffer, $\mathrm{pH}$ 9.6) and peroxidase-conjugated anti-mouse rabbit serum (Dakopatts, $1: 1000$ dilution in PBS/BSA/T) as the detecting antibody. Colour was developed with $o$-phenylenediamine (OPD, Sigma) and read at $492 \mathrm{~nm}$. The recovery is calculated as $A_{492}$ of 9BF8 incubated with $\mathrm{Mn}$ (control) $-A_{492}$ of $9 \mathrm{BF} 8$ incubated with E or L1.

EDTA treatment of $E B$. Samples $(100 \mu \mathrm{l})$ of purified EB suspensions in S-PBS containing $2.5 \mathrm{mg} \mathrm{ml}^{-1}$ were incubated with $10 \mathrm{mM}$-EDTA at $\mathrm{pH} 8$ or $\mathrm{pH} 9$ for $30 \mathrm{~min}$ at $22^{\circ} \mathrm{C}$. After centrifugation at $25000 \mathrm{~g}$ for
$30 \mathrm{~min}$, the pelleted EBs were washed once with S-PBS. Samples were used to determine their residual infectivity and neutralization by $\mathrm{mAb}$ 9BF8 or allowed to react with $\mathrm{mAb} 9 \mathrm{BF} 8$ in the absorption assay in the presence and absence of $\mathrm{Mg}^{2+}$ as described above. The amount of LPS released was measured in the supernatant with a capture-ELISA assay after treatment of the EB with proteinase $\mathrm{K}$ as described by Mearns $e t$ al. (1988). Briefly, polystyrene microtitre plates (Nunc) were coated overnight at $4{ }^{\circ} \mathrm{C}$ with $\mathrm{mAb}$ OPG $10\left(10 \mu \mathrm{g} \mathrm{ml}^{-1}\right.$ in $0.05 \mathrm{M}$-carbonate/ bicarbonate buffer, $\mathrm{pH} 9 \cdot 6$ ). After blocking for $1 \mathrm{~h}$ at $37^{\circ} \mathrm{C}$ with $5 \%$ (w/v) non-fat milk in PBS, the plates were incubated for $1 \mathrm{~h}$ at $37^{\circ} \mathrm{C}$ with the supernatants, or serial dilutions of digested EB in PBS/BSA, as standard, or PBS/BSA as controls. After several washes with PBS-T, the LPS captured by the first monoclonal was visualized by a second anti-LPS $\mathrm{mAb}$ labelled with peroxidase according to Nakane \& Kawaoi, (1974, $1: 100$ in PBS/BSA). Colour was developed with $o$ phenylenediamine (OPD, Sigma) and read at $492 \mathrm{~nm}$.

\section{Results}

\section{In vitro neutralization of serovar $L 1$ by a monoclonal antibody: interference by $\mathrm{Mg}^{2+}$}

A species-specific IgM, named 9BF8, recognizing the fourth variable domain of the MOMP (not shown) was found to neutralize the infectivity of $C$. trachomatis serovars B, D, E, L1 , L2, F, K and A but not of C, I and L3. Serovars $B a, G, H$ and $J$ were not tested. The monoclonal antibody reacted with viable chlamydia in the dot-blot assay frequently used to identify immunoaccessible antigens (Zhang et al., 1987; Peterson et al., 1988; not shown). Fluorescein-conjugated mAb 9BF8 bound to the cell surface of purified chlamydial EB in a direct immunofluorescence assay, suggesting that the relevant epitope is surface-exposed (not shown). Representative neutralizatifon curves of the infectivity of the LGV serovar $\mathrm{Ll}$ and the trachoma serovar $\mathrm{E}$ by the purified 9BF8 IgM are shown in Fig. 1. mAb 9BF8 reduced the infectivity of $\mathrm{E}$ and $\mathrm{L} 1$ by $50 \%$ at protein concentrations of 43.5 and $7.2 \mu \mathrm{g} \mathrm{ml}^{-1}$, respectively. When the neutralization assays were performed in a buffer containing divalent cations, such as HSC, mAb 9BF8 neutralized the infectivity of serovar $E$ but not of serovar $\mathrm{L} 1$. This prompted us to study the effect of each component in HSC. Addition of $\mathrm{Ca}^{2+}$ and HEPES separately or together had no effect on the neutralizing activity of $\mathrm{mAb}$ 9BF8 (not shown). It was the presence of $\mathrm{Mg}^{2+}$ that completely prevented the inhibitory activity of $\mathrm{mAb} 9 \mathrm{BF} 8$ on serovar $\mathrm{L} 1$. The inhibition of the infectivity of $\mathrm{E}$ by the monoclonal antibody was only slightly affected by the presence of $\mathbf{M g}^{2+}$ (Fig. 1). When the cation was absent from the preincubation mixture 9BF8-L1, but was added to the cells before or after the inoculation, $9 \mathrm{BF} 8$ reduced the infectivity of $\mathrm{L} 1$ by $60 \%$. Thus, the presence of $\mathbf{M g}^{2+}$ directly affected the binding of the antibody to the EB of serovar L1. To support this suggestion, mAb 9BF8 was allowed to react with increasing amounts of both serovars in the presence and 


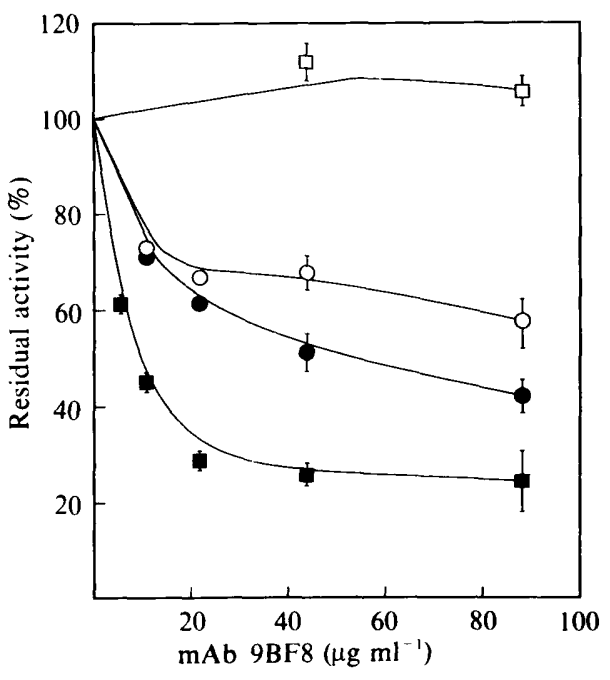

Fig. 1. Inhibition of the infectivity of serovars $E$ and $L 1$ by $m A b 9 B F 8$ in the presence and absence of $\mathrm{Mg}^{2+}$. Purified chlamydial EB of serovars $\mathrm{E}$ (circles) and $\mathrm{Ll}$ (squares) $\left(11.5 \mu \mathrm{g} \mathrm{ml}^{-1}\right.$ each) were incubated with increasing amounts of purified mAb 9BF8 in the presence (open symbols) and absence (filled symbols) of $1 \mathrm{mM}-\mathbf{M g}^{2+}$. Data shown are means and standard deviations from two triplicate experiments.

absence of $\mathrm{Mg}^{2+}$. After removal of the immune complex by sedimentation, the free antibody remaining in the supernatant was titrated with antiserum against mouse immunoglobulins. A substantial amount of free antibody was recovered when the reaction with $\mathrm{L} 1$ was done in the presence of $\mathrm{Mg}^{2+}$ (Fig. 2). No differences were observed in the amount of free antibody after absorption with $\mathrm{E}$ in the absence or presence of $\mathbf{M g}^{2+}$.

When mAb 9BF8 was digested with trypsin and the monovalent Fab fragments were assessed for neutralization of serovar $\mathrm{L} 1$, the infectivity of $\mathrm{Ll}$ was reduced in the absence and presence of $\mathrm{Mg}^{2+}$, in contrast with the intact IgM molecule (Table 1). These data let us suggest that the presence of $\mathrm{Mg}^{2+}$ induced conformational changes at the chlamydial cell surface and altered the immunoaccessibility of this domain.

\section{Interference by $\mathrm{Mg}^{2+}$ in the neutralization of other serovars}

Complement-independent neutralization experiments with $\mathrm{mAb} 9 \mathrm{BF} 8$ in the presence of $\mathrm{Mg}^{2+}$ were performed with serovars $B, D, L 2, F, K$, and A. The results are summarized in Table 2 . In serovars $L 2$ and $F$, the presence of $\mathrm{Mg}^{2+}$ negated the neutralizing activity of mAb 9BF8 almost completely, whereas the neutralization of serovar $B, D$ and $K$ and $A$ was not significantly affected by the presence of $\mathbf{M g}^{2+}$.

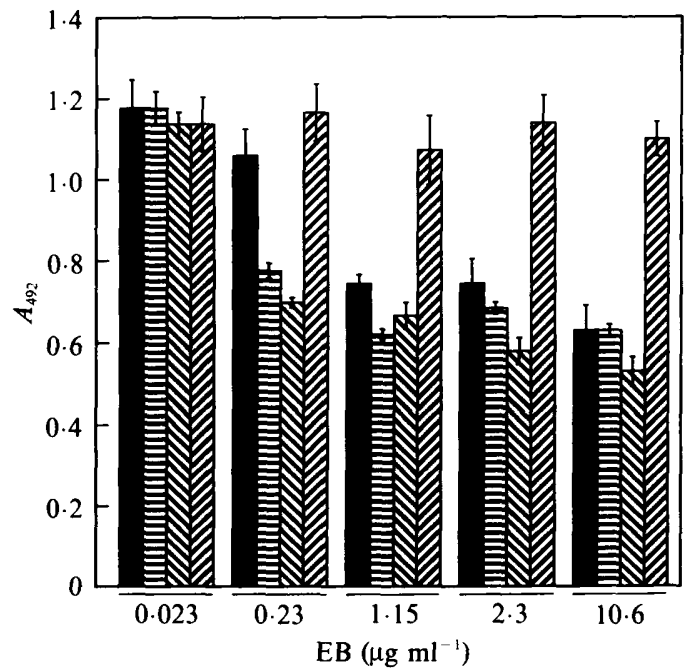

$\square \mathrm{Ll} \rightleftharpoons \mathrm{E} \quad \mathrm{NE} / \mathrm{Mg}$ WL $/ \mathrm{Mg}$

Fig. 2. Recovery of $m A b 9 B F 8$ after reaction with serovars $E$ and $L 1$ in the presence and absence of $\mathrm{Mg}^{2+}$. Samples containing $0.160 \mu \mathrm{g} \mathrm{ml}^{-1}$ mAb 9BF8 were incubated with increasing amounts of purified EB from serovars $\mathrm{E}$ and $\mathrm{Ll}$ and the $C$. psittaci strain $\mathrm{Mn}$ as control. After centrifugation, the free antibody was titrated in a capture-ELISA assay with rabbit serum against mouse immunoglobulins. Data shown are means and standard deviations from triplicate experiments.

Table 1. Inhibition of the infectivity of serovar LI by Fab fragments of $M A b 9 B F 8$ in the presence and absence of $\mathrm{Mg}^{2+}$

Data shown are means and standard deviations from triplicate experiments.

\begin{tabular}{lrrlr}
\hline \hline & \multicolumn{4}{c}{ Infectivity (IFU per field) } \\
\cline { 2 - 5 } \multicolumn{1}{c}{ Addition } & No & & With \\
$\mathrm{Mg}^{2+}$ & $(\%)$ & $\mathbf{M g}^{2+}$ & $(\%)$ \\
\hline None & $41 \pm 4$ & 100 & $43 \pm 4$ & 105 \\
9BF8 $\left(7 \mu \mathrm{g} \mathrm{m}^{-1}\right)$ & $17 \pm 6$ & 41 & $43 \pm 4$ & 105 \\
Fab $\left(20 \mu \mathrm{g} \mathrm{m}^{-1}\right)$ & $18 \pm 3$ & 44 & $20 \pm 1$ & 47 \\
\hline \hline
\end{tabular}

Table 2. Protective effect of $\mathbf{M g}^{2+}$ ions on the neutralization of the infectivity of several chlamydial serovars

EB suspensions in S-PBS were incubated with MAb 9BF8 $(1: 1)$ at $37^{\circ} \mathrm{C}$ for $45 \mathrm{~min}$ in the presence and absence of $\mathrm{Mg}^{2+}$. Samples $(100 \mu \mathrm{l})$ were applied to infect triplicate $\mathrm{McC}$ coy cell monolayers in 96-well plates. The experiment was repeated three times for each serovar.

Residual infectivity (IFU per field, \% of control)

\begin{tabular}{lrrrrrr}
\cline { 2 - 6 } & L2 & F & A & B & K & D \\
\hline 9BF8 $\left(87 \cdot 8 \mu \mathrm{g} \mathrm{ml}^{-1}\right)$ & 16 & 29 & 48 & 39 & 46 & 46 \\
9BF8 + 1 mM-Mg & 111 & 82 & 52 & 54 & 43 & 57 \\
\hline \hline
\end{tabular}




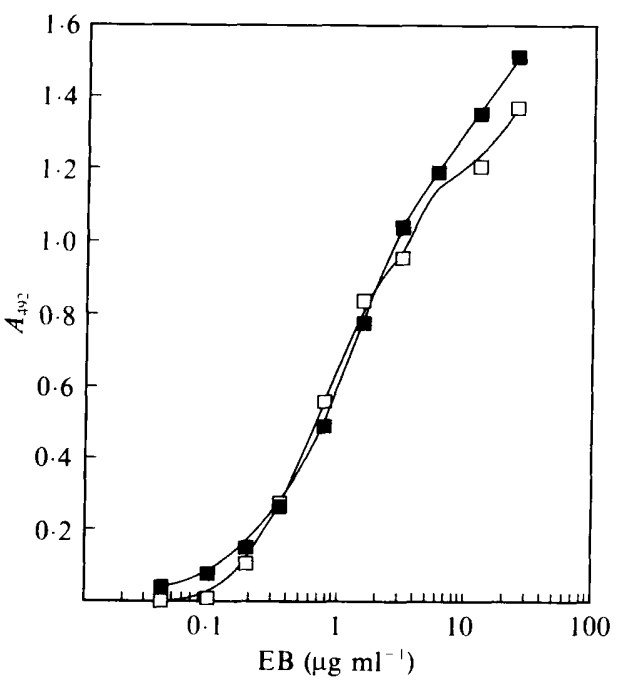

Fig. 3. Standard curves for the determination of LPS in a captureELISA assay. Purified EB from serovars E and L1 with the same protein concentration $\left(2.6 \mathrm{mg} \mathrm{ml}^{-1}\right)$ and the same EB counts were treated with proteinase $K$ and applied in twofold dilutions on microtitre plates coated with an anti-chlamydial LPS mAb (OPG10). A different anti-LPS $\mathrm{mAb}$ conjugated with horse-radish peroxidase (1 BC6) was applied for the development of the ELISA. $\square$, Serovar E; $\square$, Serovar L1.

\section{Release of LPS of serovars E and LI by EDTA treatment}

In order to determine the chlamydial compound interfering with the protective action of $\mathrm{mAb} 9 \mathrm{BF} 8$ in the presence of $\mathrm{Mg}^{2+}$ we examined the effect of EDTA at moderate alkaline $\mathrm{pH}(8.0$ and 9.0$)$ on the neutralizing activity of the $\mathrm{mAb}$ and on the release of chlamydial LPS. The residual infectivity of the pelleted EB was determined by counting inclusions, while the relative amount of released LPS was measured in the supernatant using a capture-ELISA assay. Chlamydiae were digested with proteinase $\mathrm{K}$ and used as a standard, as applied for the development of a dot-blot assay by Mearns et al. (1989). Representative titration curves of similarly proteinase-treated EB from serovars $\mathrm{E}$ and $\mathrm{L} 1$ are shown on Fig. 3. The input plotted on the abcissa represents the amount of chlamydial protein $\mathrm{ml}^{-1}$ before digestion with proteinase $K$. The curves obtained with the LGV and the trachoma serovars after proteinase treatment were always very similar.

Treatment of $\mathrm{L} 1$ with EDTA at $\mathrm{pH} 8$ reduced its infectivity by $39 \%$ when compared with $\mathrm{L} 1$ incubated at the same pH (Table 3). The inhibitory activity of 9BF8 was not affected by the EDTA treatment. The presence of $\mathrm{Mg}^{2+}$ reduced the neutralizing activity of $\mathrm{mAb} 9 \mathrm{BF} 8$ on treated chlamydia by $42 \%(26 \%$ neutralization in the presence compared to $62 \%$ in the absence of $\mathrm{Mg}^{2+}$ ).
Table 3. Neutralization of the infectivity of serovar LI by mAb $9 B F 8$ after EDTA treatment at $\mathrm{pH} 8$ in the presence and absence of $\mathrm{Mg}^{2+}$

Data shown are means and standard deviations from triplicate experiments.

\begin{tabular}{lcccc}
\hline \hline & \multicolumn{3}{c}{ Infectivity (IFU per field) } \\
\cline { 2 - 5 } \multicolumn{1}{c}{ Addition } & $\begin{array}{c}\text { No } \\
\mathrm{Mg}^{2+}\end{array}$ & $(\%)$ & $\begin{array}{l}\text { With } \\
\mathbf{M g}^{2+}\end{array}$ & $(\%)$ \\
\hline Control (L1 at pH 8.0) & & & & \\
None & $67 \pm 1$ & 100 & $69 \pm 9$ & 100 \\
9BF8 (20 $\left.\mu \mathrm{g} \mathrm{m}^{-1}\right)$ & $25 \pm 3$ & 37 & $73 \pm 1$ & 105 \\
L1 treated with EDTA at pH 8.0 & & & \\
None & $40 \pm 2$ & 100 & $43 \pm 4$ & 100 \\
9BF8 $\left(20 \mu \mathrm{g} \mathrm{ml}^{-1}\right)$ & $15 \pm 1$ & 38 & $32 \pm 2$ & 74 \\
\hline \hline
\end{tabular}

Table 4. Infectivity and LPS-release of serovars $E$ and $L 1$ after treatment with EDTA

Purified EB from serovar E and $\mathrm{Ll}\left(2 \mu \mathrm{g} \mathrm{ml}^{-1}\right)$ were incubated at $\mathrm{pH} 8$ and $\mathrm{pH} 9$ in the presence of 10 mM-EDTA. After centrifugation, the amount of LPS released in the supernatant was quantified by an ELISA assay, and the infectivity of the pelleted EB was estimated by inclusion counting. The experiment was repeated three times, means and standard deviations are shown.

\begin{tabular}{|c|c|c|c|c|}
\hline \multirow[b]{2}{*}{ Treatment } & \multicolumn{2}{|c|}{ Serovar L1 } & \multicolumn{2}{|c|}{ Serovar E } \\
\hline & $\begin{array}{c}\text { LPS } \\
\left(A_{492}\right)\end{array}$ & $\begin{array}{l}\text { Infectivity } \\
\text { (IFU per } \\
\text { field) }\end{array}$ & $\begin{array}{c}\text { LPS } \\
\left(A_{492}\right)\end{array}$ & $\begin{array}{l}\text { Infectivity } \\
\text { (IFU per } \\
\text { field) }\end{array}$ \\
\hline $\begin{array}{l}\text { Control (pH 7-2) } \\
\text { pH } 8+10 \text { mM-EDTA } \\
\text { pH } 9+10 \text { mM-EDTA }\end{array}$ & $\begin{array}{l}0.23 \pm 0.02 \\
0.83 \pm 0.04 \\
1 \cdot 31 \pm 0.12\end{array}$ & $\begin{array}{c}137 \pm 10 \\
61 \pm 5 \\
4 \pm 2\end{array}$ & $\begin{array}{l}0.20 \pm 0.09 \\
0.60 \pm 0.04 \\
0.89 \pm 0.07\end{array}$ & $\begin{array}{c}152 \pm 20 \\
113 \pm 18 \\
6 \pm 1\end{array}$ \\
\hline
\end{tabular}

The effect of EDTA at $\mathrm{pH} 8$ and $\mathrm{pH} 9$ on the infectivity of $\mathrm{E}$ and $\mathrm{L} 1$ and on the release of their LPS are presented in Table 4. In both serovars, the loss of infectivity paralleled the release of LPS. Only $2.9 \%$ of the chlamydiae from serovar $\mathrm{Ll}$ and $3.9 \%$ from serovar $\mathrm{E}$ were infectious after treatment with EDTA at $\mathrm{pH} 9$. EDTA treatment at $\mathrm{pH} 7.2$ did not significantly affect the infectivity or the release of LPS in either serovar (not shown). A considerable amount of LPS was released into the supernatant in both serovars at $\mathbf{p H ~ 9 . 0 . ~ I t ~ w a s ~} 5.7$ times the amount of the control (EB at pH 7.2) in serovar $\mathrm{L} 1$ and 4.5 times in serovar E. By comparison, the corresponding data at $\mathrm{pH} 8.0$ were 3.6 times the control in serovar $\mathrm{Ll}$ and 3.0 in serovar $\mathrm{E}$.

SDS-PAGE of the supernatant after EDTA treatment at $\mathrm{pH} 9.0$ of serovar $\mathrm{E}$ revealed two major protein bands with molecular masses of 60 and $45 \mathrm{kDa}$, respectively (Fig. 4). Probing with specific mAbs against the $60 \mathrm{kDa}$ chlamydial heat-shock protein (Bavoil et al., 1990; 


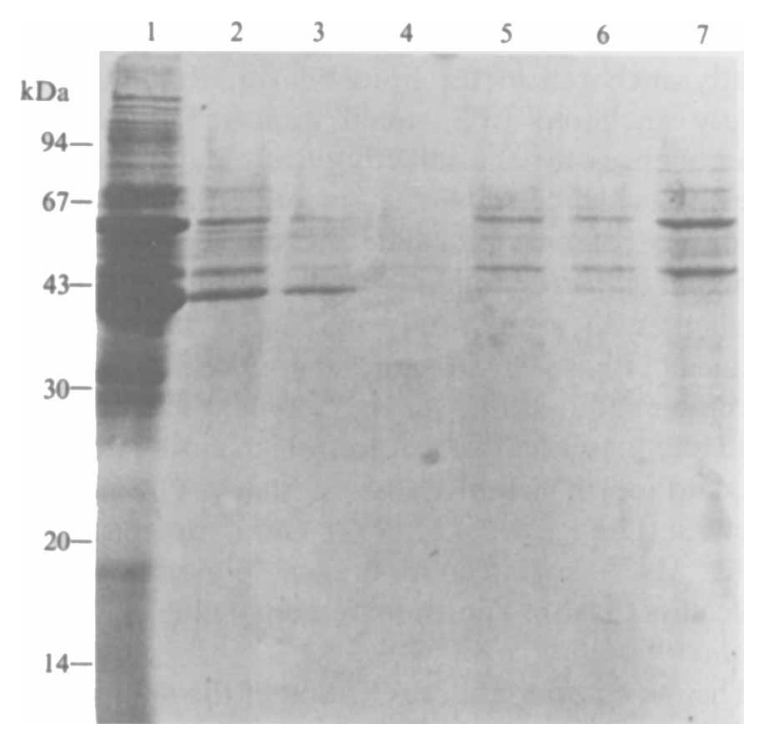

Fig. 4. Profile of the proteins released in the supernatant after EDTA treatment at $\mathrm{pH} 9.0$ of serovar E. Frozen EBs were thawed, pelleted and the pellets washed once with PBS. The washed EBs were treated with EDTA at $\mathrm{pH} 7.0$ and $\mathrm{pH} 9.0$ and centrifuged. The supernatants were subjected to SDS-PAGE and stained with Coomassie brilliant blue. Lanes: 1, EBs from serovar E; 2, supernatant of the pelleted thawed EBs; 3, PBS wash; 4, supernatant at pH 7.0; 5, supernatant

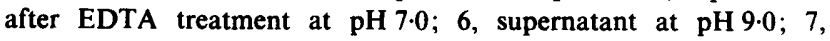
supernatant after EDTA treatment at pH 9.0. Molecular mass markers are on the left side.

Morrison et al., 1989) and the $60 \mathrm{kDa}$ cysteine-rich OMP 2 protein identified the released $60 \mathrm{kDa}$ protein band as the chlamydial stress protein (not shown).

\section{LPS release and $M g$-independent binding of $M A b 9 B F 8$ to $L I$}

Previous electron microscopy experiments with EB from a $C$. psittaci strain showed that the cell evelopes retained their rigid round shape after EDTA treatment at a pH 10 (Narita et al., 1976). Purified EB from serovar L1 were therefore incubated at $\mathrm{pH} 8$ and $\mathrm{pH} 9$ in the presence and absence of $10 \mathrm{~mm}$-EDTA, pelleted, and allowed to bind $\mathrm{mAb} 9 \mathrm{BF} 8$ in the presence and absence of $\mathrm{Mg}^{2+}$. The amount of LPS released in the supernatant was quantified as above. After the reaction of the EDTAtreated chlamydia with the antibody and removal of the immune complex by sedimentation, the amount of free antibody was quantified in the supernatant as described above. The results are illustrated in Fig. 5. At pH 8, a substantial amount of $\mathrm{mAb} 9 \mathrm{BF} 8$ bound to serovar $\mathrm{Ll}$ in the absence of the cation, while almost $100 \%$ of the antibody was recovered from the supernatant in the presence of $\mathrm{Mg}^{2+}$. Raising the $\mathrm{pH}$ to 9 in the absence of EDTA did not substantially change the two parameters,

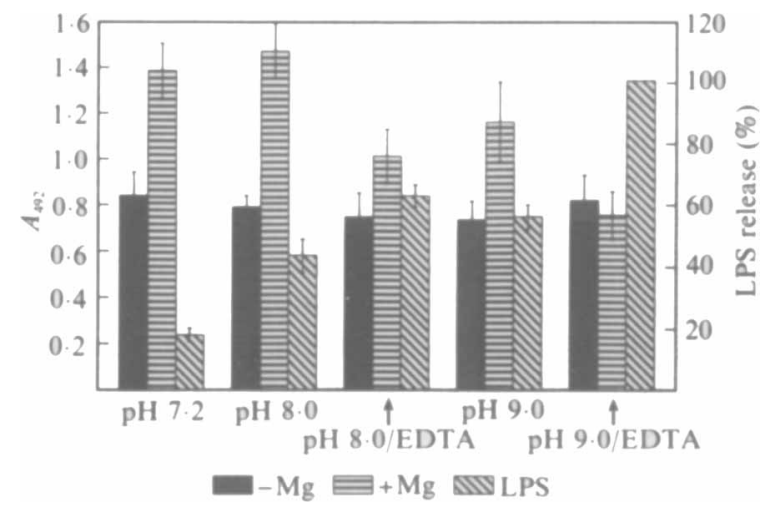

Fig. 5. Recovery of mAb 9BF8 after absorption with EDTA-treated EBs from serovar $\mathrm{Ll}$ in the presence and absence of $\mathrm{Mg}^{2+}$. $\mathrm{mAb}$ 9BF8 $\left(0 \cdot 160 \mu \mathrm{g} \mathrm{ml}^{-1}\right)$ was incubated with $2 \mu \mathrm{g}$ serovar $\mathrm{Ll} \mathrm{ml}^{-1}$ pretreated with EDTA at $\mathrm{pH} 8$ and $\mathrm{pH} 9$ and with the $C$. psittaci Mn strain as control. The amount of free $\mathrm{mAb}$ in the supernatant was titrated as described above. The amount of the LPS released by the pretreatment with EDTA at the different pH was quantified by a capture-ELISA assay.

i.e., recovery of antibody and release of LPS. Chlamydiae treated with EDTA at $\mathrm{pH} 8$ showed a $32 \%$ decrease in the amount of antibody recovered in the supernatant, suggesting that some of the mAb bound to the surface of $\mathrm{Ll}$ in the presence of $\mathrm{Mg}^{2+}$. This result corroborated the data obtained in the neutralization assay of EDTAtreated EB at the same $\mathrm{pH}$ (Table 3). After EDTAtreatment at $\mathrm{pH} 9$, antibody binding at the $\mathrm{Ll}$ surface became $\mathrm{Mg}$-independent, in that the $\mathrm{mAb}$ recovered in the presence and in the absence of $\mathbf{M g}^{2+}$ were equal. For the sake of clarity the amount of LPS released after this treatment was accorded the value of $100 \%$ (Fig. 5).

These results, together with the neutralization data obtained with the monovalent Fab fragments, lead to the suggestion that in certain chlamydial serovars, crosslinking of LPS by Mg ions resulted in steric hindrance of antibody binding to the MOMP and therefore lack of neutralization of chlamydial infectivity.

\section{Discussion}

In this report, we have studied the ability of $\mathrm{Mg}^{2+}$ to protect the infectivity of some chlamydial serovars from the neutralizing activity of a species-specific mAb directed against the MOMP. The ability of the Fab fragments of this $\mathrm{mAb}$ to neutralize chlamydial infectivity in a $\mathrm{Mg}$-independent manner indicated steric hindrance and directed our attention to the chlamydial LPS. Protection of chlamydial infectivity by $\mathrm{Mg}^{2+}$ from complement-dependent neutralization by a speciesspecific $\mathrm{mAb}$ has been previously reported by 
Peterson et al. (1988). In contrast to our results, the presence of $\mathrm{Mg}^{2+}$ did not influence the binding of the antibody to the surface of EB measured in the microimmunofluorescence assay. The authors suggested that the cation protected chlamydiae from antibody-complement attack in a similar way to the serum-resistance reported for Gram-negative bacteria with smooth LPS. The protection by $\mathrm{Mg}^{2+}$ was observed with serovars $\mathrm{E}$ and C. It is therefore very likely that the mechanisms underlying the two observations are intrinsically very different.

It is generally accepted that divalent cations play a major role in the stabilization of the outer membrane of Gram-negative bacteria by cross-linking the adjacent negatively charged LPS molecules (Hancock, 1991). Removal of the cations by chelation with EDTA results in enhanced permeabilization of the outer membrane and in destabilization and release of LPS (Leive, 1965). The effect of such treatments on the viability of the micro-organism depends upon the organism. While it is deleterious for Pseudomonas aeruginosa (Asbell \& Eagon, 1966) it does not affect many strains of Escherichia coli (Marvin et al., 1989). Our data show that treatment of serovars E and L1 with EDTA resulted in a significant loss of their infectivity. Electron microscopy studies on the meningopneumonitis strain of $C$. psittaci by Manire and co-workers (Narita et al., 1976) showed intact rigid envelopes that had lost their internal contents and part of their cell surface components after EDTA treatment at pH 10. SDS-PAGE of the released protein-carbohydrate-lipid complex revealed two bands with molecular masses of approximately 17 and $13 \mathrm{kDa}$, respectively (Narita \& Manire, 1976). Recently, the 18 kDa chlamydial histone analogue has been partially solubilized by a similar treatment (Hackstadt, 1991). The protein profile of the material released after EDTA treatment at $\mathrm{pH} 9 \cdot 0$ observed in this study resembled the protein pattern obtained after solubilization of chlamydial EB with Triton X-100 (Morrison et al., 1989). Although the role of the $60 \mathrm{kDa}$ (or $57 \mathrm{kDa}$ ) heat shock protein in the pathogenesis of chlamydial disease has been well established, its function in the assembly of the chlamydial outer membrane is hypothetical (Bavoil et al., 1990). At present, the role of the $45 \mathrm{kDa}$ protein on the surface of chlamydiae is not known.

Chlamydial LPS has been shown to be liberated from the outer membrane during the reorganization of the cell walls in the developmental cycle of chlamydia, and LPS molecules have been detected incorporated in the cell membrane of the host cells (Karimi et al., 1988). Moreover, Birkelund et al. (1989) have reported that LPS release into the supernatant can be provoked by anti-LPS monoclonal antibodies. The infectivity of the antibodytreated pelleted EB was not tested in their study. It is tempting, however, to speculate that, while part of the
LPS can be easily shed or liberated, another part remains tightly anchored in the lipid bilayer. Removal of this tightly anchored LPS would appear to have severe consequences for the infectivity of chlamydia. Several lines of evidence implicate smooth LPS in conferring hindrance of epitopes. The smooth Phase I LPS of Coxiella burnetti hinders the access of anti-phase II antibodies to a multitude of shared surface protein antigens. Phase II cells are therefore less promising vaccine candidates (Hackstadt, 1988). The core glycolipid region is usually not accessible to antibodies against the surface of wild strains in many Gram-negative bacteria (Luederitz et al., 1982). Our data are suggestive of a $\mathrm{Mg}^{2+}$-mediated hindrance provoked by LPS molecules that are known to be deeply rough (Nurminen et al., 1985).

The most important implication of the data presented here is, however, the difference in the surface topology between the chlamydia serovars that are protected by $\mathrm{Mg}^{2+}$, such as serovars L1, L2 and F, and those that are not. The differences may occur in the topology, conformation or orientation either of the LPS molecules or of the MOMP epitope or of both. Complexing of $\mathbf{M g}^{2+}$ ions with a proteinaceous chlamydial component can also not be excluded. In conclusion, differences in the surface topology of certain chlamydial serovars are responsible for their protection from antibody attack, possibly due to LPS cross-linking by physiological concentrations of $\mathrm{Mg}$ ions. The high degree of resistance to antibody-mediated neutralization may have important implications in vivo.

We thank Mrs Giorgia Conidou for growing and purifying the chlamydial stocks, Dr Leonidas Tzouvelekis for helpful discussions and Dr Subir Bose for invaluable help during the preparation of the manuscript.

\section{References}

Asbell, M. A. \& EAGon, R. G. (1966). The role of multivalent cations in the organization and structure of bacterial cell walls. Biochemical and Biophysical Research Communications 22, 664-671.

Bavoil, P., Stephens, R. S. \& Falkow, S. (1990). A soluble $60 \mathrm{kDa}$ antigen of Chlamydia spp. is a homologue of Escherichia coli GroEL. Molecular Microbiology 4, 461-469.

Bidlack, J. M. \& Mabie, P. C. (1986). Preparation of Fab fragments from a mouse monoclonal IgM. Journal of Immunological Methods 91 , 157-162.

Birkelund, S., Lundemose, A. G. \& Christiansen, G. (1988). Chemical cross-linking of Chlamydia trachomatis. Infection and Immunity 56, 654-659.

Birkelund, S., Lundemose, A. G. \& Christiansen, G. (1989). Immunoelectron microscopy of lipopolysaccharide in Chlamydia trachomatis. Infection and Immunity 57, 3250-3253.

Caldwell, H. D. \& PerRy, L. J. (1982). Neutralization of Chlamydia trachomatis infectivity with antibodies to the major outer membrane protein. Infection and Immunity 38, 745-754. 
Goswami, P. C., Vretou, E. \& Bose, S. K. (1990). Extensive heterogeneity of the protein composition of Chlamydia trachomatis following serial passage in two different cell lines. Journal of General Microbiology 136, 1623-1629.

HACKSTADT, T. (1988). Steric hindrance of antibody binding to surface proteins of Coxiella burnetti by Phase I lipopolysaccharide. Infection and Immunity 56, 802-807.

HackstadT, T. (1991). Purification and N-terminal amino acid sequences of Chlamydia trachomatis histone analogs. Journal of Bacteriology 173, 7046-7049.

HANCOCK, R. E. W. (1991). Bacterial outer membranes: evolving concepts. ASM News 57, 175-182.

Karimi, S. T., Schloemer, R. H. \& Wilde, C. E., III (1989). Accumulation of chlamydial lipopolysaccharide antigen in the plasma membranes of infected cells. Infection and Immunity 57, 17801785.

LEIVE, L. (1965). Release of lipopolysaccharide by EDTA treatment of Escherichia coli. Biochemical and Biophysical Research Communications 21, 290-296.

Luederitz, O., Freudenberg, M. A., Galanos, C., Lehmann, V., RIETSHeL, E. TH. \& SHAW, D. H. (1982). Lipopolysaccharides of Gram-negative bacteria. Current Topics in Membrane Transport 17, 79-151.

Marvin, H. J. P., Ter Beest, M. B. \& Witholt, B. (1989). Release of outer membrane fragments from wild-type Escherichia coli and from several E. coli lipopolysaccharide mutants by EDTA and heat shock treatments. Journal of Bacteriology 171, 5262-5267.

Mearns, G., Richmond, S. J. \& Storey, C. C. (1988). Sensitive immune dot blot for diagnosis of Chlamydia trachomatis infection. Journal of Clinical Microbiology 26, 1810-1813.

Morrison, R. P., Belland, R. J., Lyng, K. \& Caldwell, H. D. (1989). Chlamydial disease pathogenesis. The $57 \mathrm{kD}$ chlamydial hypersensitivity antigen is a stress response protein. Journal of Experimental Medicine 170, 1271-1283.

NAKANE, P. K. \& KaWAOI, A. (1974). Peroxidase-labeled antibody: A new method of conjugation. Journal of Histochemistry and Cytochemistry 22, 1084-1091.

Narita, T. \& Manire, G. P. (1976). Protein-carbohydrate-lipid complex isolated from the cell envelope of Chlamydia psittaci in alkaline buffer and ethylenediaminetetraacetate. Journal of Bacteriology 125, 308-316.
NARITA, T. Wyrick, P. B. \& MANIRE, G. P. (1976). Effect of alkali on the structure of cell envelopes of Chlamydia psittaci elementary bodies. Journal of Bacteriology 125, 300-307.

Nurminen, M., Rietschel, E. T. \& Brade, H. (1985). Chemical characterization of Chlamydia trachomatis lipopolysaccharide. Infection and Immunity 48, 573-575.

Peeling, R., Maclean, I. W. \& Brunham, R. (1984). In vitro neutralization of Chlamydia trachomatis with monoclonal antibody to an epitope on the major outer membrane protein. Infection and Immunity 46, 484-488.

Peterson, E. M., Zhong, G. M., Carlson, E. \& De la Maza, L. M. (1988). Protective role of magnesium in the neutralization by antibodies of Chlamydia trachomatis infectivity. Infection and Immunity 56, 885-891.

Pouletty, P., Martin, J., Catalan, F., Garcia-Gonzalez, M., Morellet, I., BetTINGer, S. \& Kadouche, J. (1988). Optimization of a rapid test by using fluorescein-conjugated monoclonal antibodies for detection of Chlamydia trachomatis in clinical specimens. Journal of Clinical Microbiology 26, 267-270.

TAYLOR, H. R. \& Prendergast, R. (1987). Attempted oral immunization with chlamydial lipopolysaccharide $\mathrm{ml-unit}$ vaccine. Investigations in Ophthalmology and Visual Sciences 21, 422-433.

VRetou, E., Goswami, P. C. \& Bose, S. K. (1989). Adherence of multiple serovars of Chlamydia trachomatis to a common receptor on HeLa and McCoy cells is mediated by thermolabile protein(s). Journal of General Microbiology 135, 3229-3237.

Vretou, E., Spiliopoulou, D. \& PSarrou, E. (1991). Topological studies on the major outer membrane protein of Chlamydia trachomatis with an adherence-inhibiting monoclonal antibody. Molecular recognition in host-parasite interactions. Abstract no. 21. Porvoo: FEMS Symposium.

Vretou, E., Mendis, A., Psarrou, E., Tsoumaris, L., Conidou, G. \& SPILIOPOULOU, D. (1992). Unusual prevalence of the rare serovar Da of Chlamydia trachomatis in Greece detected by monoclonal antibodies. Sexually Transmitted Diseases 19 (in the Press).

Zhang, Y.-X., Stewart, S., JosePh, T., TAYloR, H. R. \& CaldWell, H. D. (1987). Protective monoclonal antibodies recognize epitopes located on the major outer membrane protein of Chlamydia trachomatis. Journal of Immunology 138, 575-581. 